\title{
RESTORATION IN THE INANGAHUA AREA
}

\author{
S. G. Hamblett* and H. W. Yeatman*
}

The Inangahua "Disaster Area" included twelve miles of the Buller River Valley from Lyell down to Berlin's and five miles of the Inangahua River Valley up to the Landing. The area contained about 50 single story buildings at Inangahua Camp, 20 at Inangahua Junction as we 11 as about 30 farm dwellings with their outbuildings spread along the valleys。

Inangahua Camp had two Churches, a school, a hall, a plunket room, a store, a garage, two motels, a highways depot and an Electricity Department substation, while at Inangahua Junction there was the Post Office, a hotel, a shop and tearooms, a transport depot and the railway station.

During the earthquake all the buildings in the disaster area were damaged to some extent and about 15 to 20 older buildings were so badly damaged that they were not worth repairing。

The day after the earthquake, plans were being laid for the $E$. and W.D. Commission to collaborate with Ministry of Works in arranging for the restoration of the damaged buildings within the "Disaster Area" . The original idea was that under section 16 of the E. and W.D. Act the Commission would exercise its option to reinstate or repair insured properties and the Ministry of Works would act as agents for the Commission in letting contracts for restoration. On this basis, arrangements were made for a small team of Ministry of Works Building Overseers to work with a Commission assessor in letting on-the-spot contracts. Arrangements were made for the Army to set up a field kitchen at Inangahua Camp and meals were to be provided for contractors' men who would sleep in the hall, etc., until the-first houses were repaired and habitable.

There were one or two local builders in the Reefton area, but they had limited resources and plenty of work ahead of them so the Canterbury Master Builders' Association was approached to see if Canterbury firms would help and several Christchurch firms sent representatives to the area to size up the task.

It gradually became necessary to modify this plan for a number of reasons, and it was not possible to start work on the restoration of buildings as quickly as it had been hoped.

Early activities in the disaster area included the removal of furniture, etc., from damaged houses to safety, also cleaning up the glass, broken crockery and spilled foodstuffs, etc. Insurance assessors were also assessing damage to house contents. While such work was going on and the restoration of access and communications was in progress, the building overseers made a careful inspection of each building and prepared a schedule and estimate of cost for its restoration. These schedules were first completed for some of the Government Departmental houses and after further inspection by contractors' representatives, tenders were prepared, negotiations completed and the first contracts let.

+ Ministry of Works, Christchurch. 
When the contractors' forces arrived from Christchurch, they were based at Reefton 20 miles from Inangahua and travelled to and fro daily. In Reefton, accommodation was under some pressure, but one contractor managed to rent a house and another set up a caravan in the camping ground.

It was not possible to let contracts on behalf of the $E_{\text {. }}$ and $W_{0} D_{0}$ Commission for the speedy reinstatement of private buildings for the following reasons:

1. Some buildings were under-insured and a few had no insurance cover at all.

2. Some buildings were in very poor condition at the time of the earthquake and the Commission's liability was limited to the indemnity value of the building. In many cases this was quite inadequate to cover the cost of the restoration to normal building standards.

3. Sewage disposal was via septic tanks and damage to these or the associated pipework was not covered by insurance.

4. The farms had a number of adjuncts which were not covered by fire insurance and therefore had no earthquake insurance cover. These were items such as water supplies, concrete outbuildings and yards, drains, exterior power lines, cables, etc.

5. There was no early indication how costs beyond the insurance cover would be met in the very common case where the owner did not have the extra money needed.

6. Owners' plans and decisions could not be finalised until all relevant information had been obtained. This included the nature and extent of current insurance cover, the likely cost of all the repairs needed, the views of any existing mortgagees and the availability of further money.

To assist owners to make their decisions, a small committee made up of a Commission assessor, a Works' building overseer and the Rev. $M$ 。 Smart interviewed each individual owner as soon as all the facts of his situation had been established. These were explained to him and the various alternatives discussed with him so that he could make up his mind whether he should accept what insurance money was available and arrange his own repairs as best he could, or whether he should have the work done by contract under Ministry of Work' supervision or whether he should sell up.

It is of interest that six months after the earthquake there are still several private properties whose future is undecided.

Government Departments involved in the Inangahua area set about their own affairs restoring the services they operated. These were mainly Railways, Post Office, N.Z.E.D. and Ministry of Works as agent for the National Roads Board。 Such work is dealt with elsewhere。

The only normal services provided in the area by the local authorities were the County roads. Inangahua Camp has two makeshift water supplies, one in the care of Ministry of Works and the other belonging to N.Z.E.D. These have both been patched up in a temporary way, but proposals for an improved supply are under investigation.

Restoration of the various departmental residences was entrusted to Ministry of Works and this was dealt with similarly to the service 
provided for the restoration of private property except that there were no complications about the letting of contracts.

Speaking quite generally of the type of building repairs needed, a number of buildings had been thrown off their foundations and in other cases the foundations were on unstable ground which had subsided. The first step in reinstatement was to jack up the building so that broken or rotten piles and any broken floor members could be renewed and the building was then reset on sound foundations.

Other general repalrs related to damaged chimneys and fireplaces. Also, roof (especially tiled roofs) and ceiling repairs were commonly associated with chimey damage.

A number of disused houses in reasonable condition or well worth repair were available in the area and seven of these are being used as replacements for dwellings beyond repair. One new farm house is being built and four farmers have left their farms since the earthquake. 


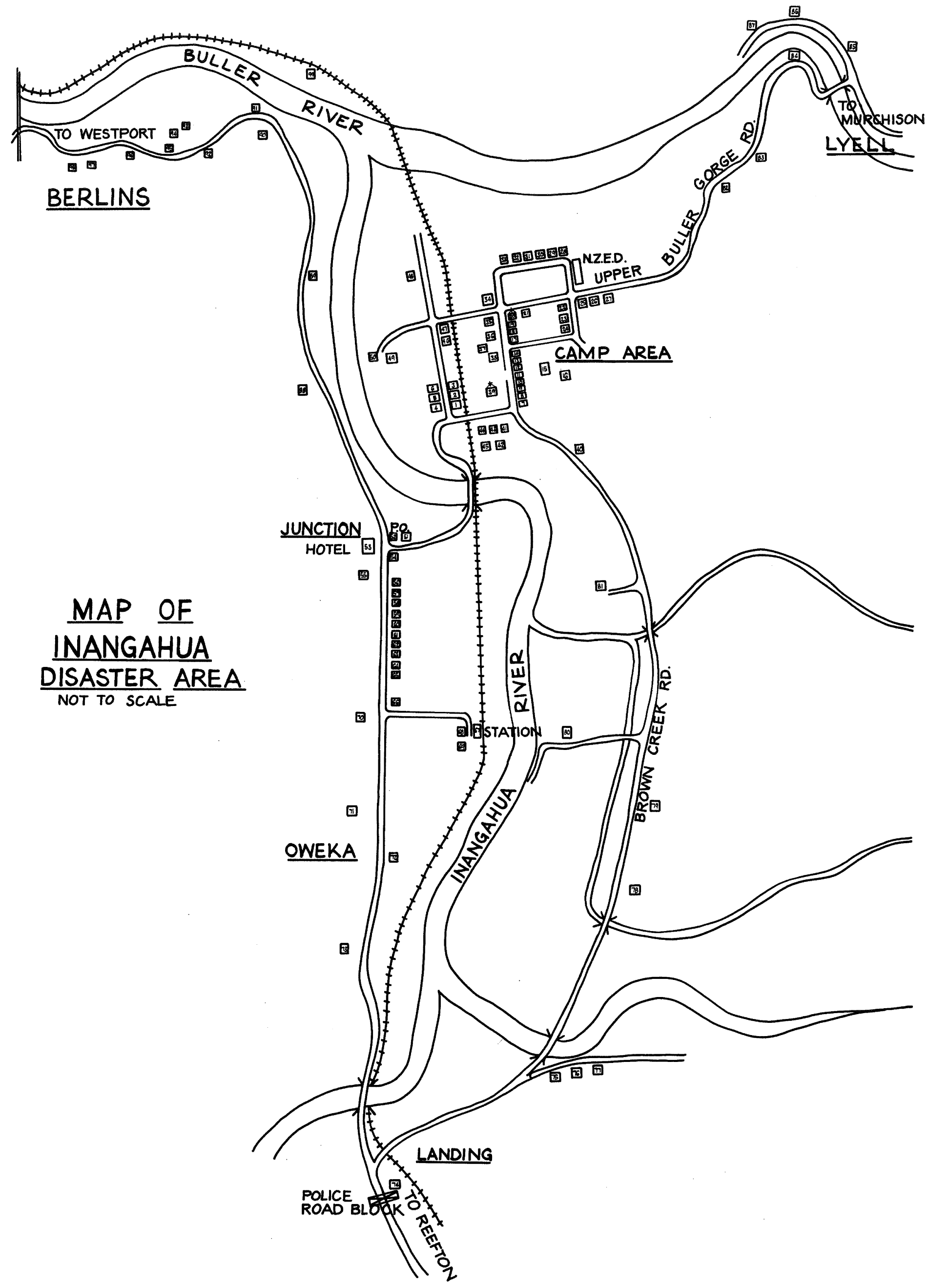

